\section{Disaster management and emerging technologies: a performance-based perspective}

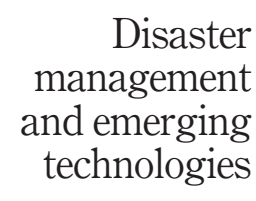

1093

Carlo Vermiglio and Guido Noto

Department of Economics, University of Messina, Messina, Italy

Manuel Pedro Rodríguez Bolívar

Department of Accounting and Finance, University of Granada, Granada, Spain, and

Vincenzo Zarone

Department of Economics and Management, University of Pisa, Pisa, Italy
Received 25 February 2021 Revised 15 May 2021 8 July 2021 Accepted 8 July 2021

\begin{abstract}
Purpose - This paper aims to analyse how emerging technologies (ETs) impact on improving performance in disaster management (DM) processes and, concretely, their impact on the performance according to the different phases of the DM cycle (preparedness, response, recovery and mitigation).

Design/methodology/approach - The methodology is based on a systematic review of the literature. Scopus, ProQuest, EBSCO and Web of Science were used as data sources, and an initial sample of 373 scientific articles was collected. After abstracts and full texts were read and refinements to the search were made, a final corpus of 69 publications was analysed using VOSviewer software for text mining and cluster visualisation.

Findings - The results highlight how ETs foster the preparedness and resilience of specific systems when dealing with different phases of the DM cycle. Simulation and disaster risk reduction are the fields of major relevance in the application of ETs to DM.

Originality/value - This paper contributes to the literature by adding the lenses of performance measurement, management and accountability in analysing the impact of ETs on DM. It thus represents a starting point for scholars to develop future research on a rapidly and continuously developing topic.
\end{abstract}

Keywords Emerging technologies, Disaster management, Performance,

Systematic literature review, VOSviewer, Emergency response

Paper type Research paper

\section{Introduction}

Despite the rising number of catastrophic events occurring in recent years, disaster management (DM) has received little attention from the interdisciplinary accounting community (Lai et al., 2014; Sargiacomo et al., 2014; Walker, 2014; Sciulli, 2018; Perkiss and Moerman, 2020; Sargiacomo and Walker, 2020).

(c) Carlo Vermiglio, Guido Noto, Manuel Pedro Rodríguez Bolívar and Vincenzo Zarone. Published by Emerald Publishing Limited. This article is published under the Creative Commons Attribution (CC BY 4.0) license. Anyone may reproduce, distribute, translate and create derivative works of this article (for both commercial and non-commercial purposes), subject to full attribution to the original publication and authors. The full terms of this license may be seen at http://creativecommons.org/ licences/by/4.0/legalcode 
MEDAR

30,4

1094

A key aspect of DM theory and practices is related to the information systems used to support decision-making and to measure, manage and report the performance of the whole DM cycle (see, amongst others, Carreño et al., 2007). Information systems have widely supported disaster practitioners in recent decades, providing an increasing volume of data gathered through emerging technologies (ETs), such as big data, Internet of Things (IoT) (Yang et al., 2013; Shah et al., 2019), machine learning, artificial intelligence (AI), remote sensing, cloud computing, social media communication (Alexander, 2014) and blockchain.

ETs are science-based innovations which provide great transformative potential for an industry, in an "early phase of development" (Boon and Moors, 2008) and can lead to "radical innovations" (Day and Schoemaker, 2000) and/or allow an evolutionary process of technical, institutional and social change; however, they bring risks of uncertainty in terms of network effects, costs and social and ethical concerns (Halaweh, 2013).

All these technologies are spreading their value in a growing variety of domains, effectively contributing to the planning, decision-making, accounting and auditing process of public and private organisations (Ndou et al., 2018; Bonsón and Bednárová, 2019; Lamboglia et al., 2020; Lombardi and Secundo, 2020; Rodríguez-Bolívar et al., 2021; TingeyHolyoak et al., 2021; De Santis and D’Onza, 2021; Lombardi et al., 2021).

Indeed, the implementation of digital technologies are becoming increasingly relevant for corporate and performance management (Oliver, 2018; Marrone and Hazelton, 2019; Wang et al., 2020a, 2020b; Chatterjee et al., 2021; Jun et al., 2021), and especially ETs have demonstrated in the last years to be particularly supportive in fostering these issues in health care (Spanò and Ginesti, 2021), transportation (Chhabra et al., 2021), manufacturing (Rezaei et al., 2017) and so on.

With specific regards to DM, extant studies have mainly focused on how technology could support data gathering and visualisation (Fajardo and Oppus, 2010) as well as knowledge management (Inan et al., 2018; Raman et al., 2018; Oktari et al., 2020). Conversely, literature reviews have focused on how specific technologies influence DM (Kankanamge et al., 2019), how they support supply chain management (Ivanov et al., 2019) or how they can be applied to deal with risks in small- and medium-sized enterprises (Verbano and Venturini, 2013).

To date, various streams of research across different disciplines, such as information science, computer science and engineering, have focused on the impact of ETs on disaster and emergency response.

However, to the authors' knowledge, limited attention has been devoted to understanding how ETs could support performance measurement, management and accountability in the specific setting of DM processes. To fill this gap, this study develops a systematic literature review (SLR) analysing how ETs impact on improving performance in DM, altering and changing DM processes to enhance resilience according to the different phases of the DM cycle (preparedness, response, recovery and mitigation). We used Scopus, ISI Web of Science, ProQuest and EBSCO as the data sources. We selected academic journal articles within the business, management and accounting categories.

The paper is structured as follows. Section 2 presents a theoretical background that links literature on DM, ETs and performance. Section 3 explains the methodology and clarifies the research question, and Section 4 presents the results of the SLR. Finally, the discussion and conclusions are presented.

\section{Theoretical background}

\subsection{An overview of disaster management}

The frequency and magnitude with which natural disasters (earthquakes, floods, landslides, droughts, storms, etc.) have occurred in recent decades are alarming. According to EM-DAT [1], 
over the last 20 years, disasters have claimed approximately 1.23 million lives and affected a total of over 4 billion people, leading to US\$2.97tn in economic losses worldwide. During the same timeframe, a total of 7,348 disasters related to natural hazards have occurred worldwide.

The concept of disasters is extremely complex and multidimensional in nature; it can be discussed by drawing on several connected fields of research (Quarantelli, 1998).

According to the definition proposed by the United Nations Office for Disaster Risk Reduction, a disaster is:

[...] a serious disruption of the functioning of a community or a society at any scale due to hazardous events interacting with conditions of exposure, vulnerability and capacity, leading to one or more of the following: human, material, economic and environmental losses and impacts [2].

DM refers to the organisation, planning and application of measures aimed at preparing for, responding to and recovering from disasters. This topic has been widely discussed in the academic literature in recent decades through different perspectives (Faulkner, 2001; Pearce, 2003; Lettieri et al., 2009) and, most recently, with a specific focus on how firms (Kraus et al., 2020; Ferrigno and Cucino, 2021) and public institutions (Steen and Brandsen, 2020) have reacted to the COVID-19 pandemic. Social scientists frame disasters from three different perspectives: the hazard, the vulnerability and the holistic view (Berg and De Majo, 2017).

Under the hazard paradigm, disasters are considered extreme physical events with accidental causes and no human or cultural influence on their origin and scope; therefore, DM is mainly focused on post-disaster short-term measures, such as recovery, relief and humanitarian aid for those who need help (Alexander, 1997).

This traditional view has been replaced by the vulnerability paradigm, rooted in development studies, in which disasters are considered the results of natural causes related to the vulnerability of the surrounding social, economic and political environment (Cutter, 1996; McEntire, 2005; Buckle, 2005; Adger, 2006). Natural disasters, rather than being only uncontrollable events, greatly depend on some structural constraints of the population hit by catastrophic events (Wisner et al., 2004).

Assuming this renewed approach, Gilbert (1998) stated that a "disaster is no longer experienced as a reaction; it can be seen as an action, a result, and more precisely, a social consequence." This broader perspective sheds light on how human activity, social order and development paths characterise the breadth and severity of natural disasters over time. According to Perry (1998), "vulnerability is socially produced," but it "may be also related to the state of technology," as information systems and ETs play a supportive role and have a key relevance within the various phases of DM (Von Lubitz et al., 2008).

The increase in the occurrence of natural disasters sheds light on the inadequacy of traditional DM processes and practices around the globe. To tackle the wickedness (Rittel and Webber, 1973; Head and Alford, 2015; Pesch and Vermaas, 2020) of such problems and reduce their intrinsic complexity, scholars have highlighted the importance of collaborative networks amongst public institutions (Waugh and Streib, 2006; Ansell et al., 2010; Comfort et al., 2012; Kapucu and Garayev, 2016), coordination mechanisms to respond and react to the emergence of problems (Moynihan, 2008; Boin et al., 2013; Kuipers et al., 2015), competencies and leadership behaviours (Rosenthal and Kouzmin, 1997; Van Wart and Kapucu, 2011) and capacity building and community awareness (Kitagawa, 2021). All these aspects are important in disaster and emergency situations characterised by complexity, urgency and uncertainty (Kapucu and Van Wart, 2008).

The multiple threats posed by disasters suggest the adoption of a holistic view of DM with a more strategic focus on the actions and tools targeted to reduce exposure and 
MEDAR

30,4

1096

vulnerability to disasters (Berg and De Majo, 2017). The holistic view marks a paradigm shift from responsive to proactive management of natural hazards based on the principles of resilience and disaster risk reduction (Manyena, 2006; Demiroz and Haase, 2019). The key phases of the DM cycle can be summarised in Figure 1.

DM requires and generates a huge amount of data coming from different sources, which must be reliable, accurate and real time. Through these data, DM practitioners can gather information on the features, locations and prospective impacts of threats, providing essential inputs for managing all the phases of the disaster cycle in a timely and effective way (Yu et al., 2019). ETs have, to date, offered opportunities to improve the management of several fields. Table 1 shows the main applications discussed in the academic literature.

These technologies are considered to have a high impact on each of the phases displayed in Table 2, although all of them are valuable for the whole DM cycle.

\subsection{Performance in the disaster management context}

Performance is one of the most explored topics by business and public administration scholars in the last half century. It is a broad concept discussed by different streams of literature, which range from the measurement of performance to management accounting and control, behavioural economics and so on (Moynihan, 2008; Ferreira and Otley, 2009; Bititci et al., 2012).

The literature usually focuses on performance by adopting three lenses that are strongly connected: performance measurement (Bititci et al., 2012), performance management (Ferreira and Otley, 2009) and accountability (Roberts, 1991; Gray, 1992).

Performance measurement is the activity of collecting data, defining indicators and computing such indicators to evaluate the ability of a certain entity to achieve strategic goals (Eccles, 1991; Hudson et al., 2001).

If performance measurement is concerned with what and how to measure, performance management is instead focused on the utilisation of such information in decision-making processes (Ferreira and Otley, 2009; Bititci et al., 2012). In this sense, performance management could be defined as the process of creating the context for performance (Lebas, 1995). Performance management comprehends the whole process starting from the

Figure 1.

Disaster risk management cycle. Our elaboration

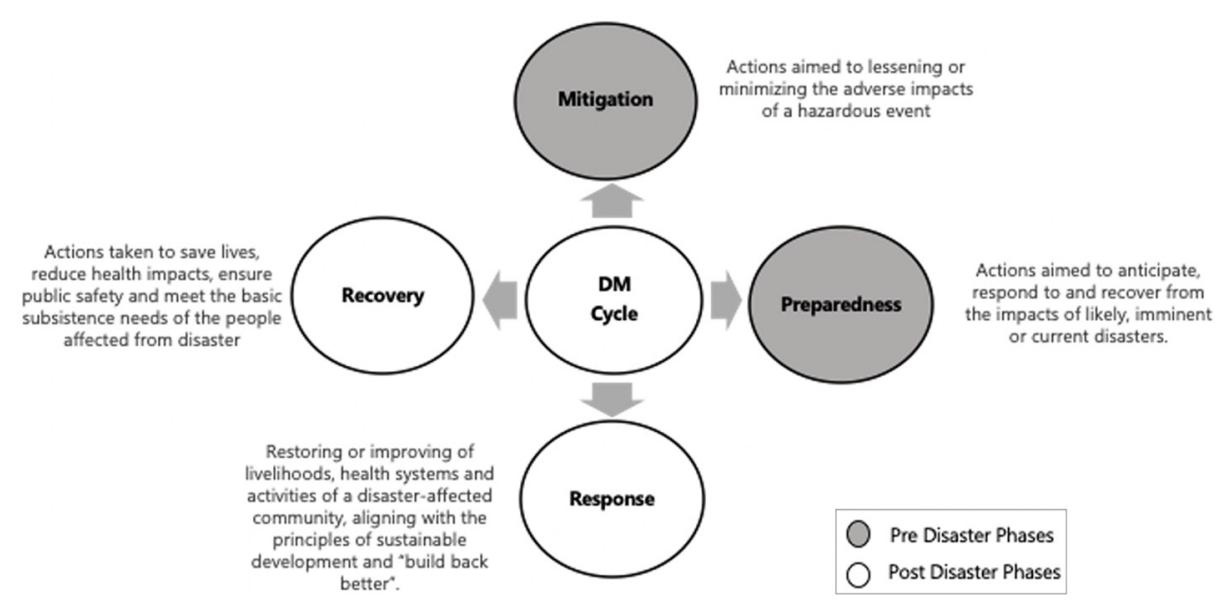




\begin{tabular}{|c|c|c|c|c|}
\hline Technology & Description & Main applications & $\begin{array}{l}\text { Main applications } \\
\text { in DM }\end{array}$ & management \\
\hline $\begin{array}{l}\text { Internet of } \\
\text { things (IoT) }\end{array}$ & $\begin{array}{l}\text { IoT refers to the networking of physical } \\
\text { objects using embedded sensors and } \\
\text { other devices that collect and transmit } \\
\text { information about real-time activity } \\
\text { within the network (Harbet, 2017) }\end{array}$ & $\begin{array}{l}\text { Location finding } \\
\text { Big data processing } \\
\text { Mobility management } \\
\text { (Asghari } \text { et al., 2019) }\end{array}$ & Response & $\begin{array}{l}\text { and emerging } \\
\text { technologies }\end{array}$ \\
\hline $\begin{array}{l}\text { Artificial } \\
\text { intelligence (AI) }\end{array}$ & $\begin{array}{l}\text { AI is the ability of a machine to learn } \\
\text { from experience, adjust to new inputs } \\
\text { and perform human-like tasks. } \\
\text { AI systems can be used either to } \\
\text { support/assist human decision-makers } \\
\text { or to replace them (Duan } \text { et al., 2019) }\end{array}$ & $\begin{array}{l}\text { Process automation to perform specific } \\
\text { tasks } \\
\text { Cognitive insights using machine } \\
\text { learning algorithms to detect patterns in } \\
\text { vast volumes of data and interpret their } \\
\text { meaning } \\
\text { Cognitive engagement using natural } \\
\text { language processing tools to provide } \\
\text { prompt response to specific needs } \\
\text { (Davenport and Ronanki, 2018) }\end{array}$ & $\begin{array}{l}\text { Mitigation/ } \\
\text { prevention }\end{array}$ & 1097 \\
\hline $\begin{array}{l}\text { Big data } \\
\text { analytics } \\
\text { (BDA) }\end{array}$ & $\begin{array}{l}\text { BDA management involves the } \\
\text { processing of huge amounts of data } \\
\text { coming from different sources in } \\
\text { different formats to acquire intelligence } \\
\text { from the data. } \\
\text { BDA can be viewed as a sub-process in } \\
\text { the overall process of insight extraction } \\
\text { from big data (Gandomi and Haider, } \\
\text { 2015) }\end{array}$ & $\begin{array}{l}\text { Data management } \\
\text { Data analytics, e.g. modelling, analysis } \\
\text { and interpretation of results }\end{array}$ & $\begin{array}{l}\text { Emergency } \\
\text { response/recovery }\end{array}$ & \\
\hline $\begin{array}{l}\text { Remote sensing } \\
\text { (RS) }\end{array}$ & $\begin{array}{l}\text { RS provides observation of some } \\
\text { physical parameters in a mapping } \\
\text { frame at a given time or period (Toth } \\
\text { and Jozkow, 2016) }\end{array}$ & $\begin{array}{l}\text { Image and spatial data acquisition for } \\
\text { topographic mapping } \\
\text { Remote platform control, e.g. satellite or } \\
\text { unmanned aerial systems or vehicles } \\
\text { like drones }\end{array}$ & $\begin{array}{l}\text { Preparedness/ } \\
\text { response }\end{array}$ & \\
\hline $\begin{array}{l}\text { Geospatial data } \\
\text { (GIS) }\end{array}$ & $\begin{array}{l}\text { GIS provides the geographic and } \\
\text { location information of different data } \\
\text { objects connected with a specific place } \\
\text { or location, which can then be mapped } \\
\text { (Barcevicius } \text { et al., 2019) }\end{array}$ & $\begin{array}{l}\text { Earth observation } \\
\text { (Breunig et al., 2020) }\end{array}$ & Mitigation/recovery & \\
\hline $\begin{array}{l}\text { Robotics and } \\
\text { automation } \\
\text { (RA) }\end{array}$ & $\begin{array}{l}\text { RA technologies automate repetitive, } \\
\text { routine, rule-based human tasks, aiming } \\
\text { to bring benefits to organisations } \\
\text { (Ivancic } \text { et al., 2019) }\end{array}$ & $\begin{array}{l}\text { Industry } 4.0 \\
\text { Health-care industry } \\
\text { Emergency management } \\
\text { Smart city applications (Macrorie } \text { et al., } \\
\text { 2019) }\end{array}$ & Response/recovery & \\
\hline Social media & $\begin{array}{l}\text { Social media is an umbrella term and a } \\
\text { revolutionary trend which refers to } \\
\text { online blogs, micro-blogs, social } \\
\text { networking, forums, collaborative } \\
\text { projects and the sharing of photos and } \\
\text { videos (Xu et al., 2019) }\end{array}$ & $\begin{array}{l}\text { Crowdsourcing } \\
\text { Communication during emergency and } \\
\text { disaster management } \\
\text { (Harrison and Johson, 2016; Mehta et al., } \\
\text { 2017a, 2019 b) }\end{array}$ & Response & \\
\hline Blockchain & $\begin{array}{l}\mathrm{BC} \text { is a distributed peer-to-peer ledger } \\
\text { that provides a way for information to } \\
\text { be recorded, aggregated and shared } \\
\text { within a heterogeneous community of } \\
\text { participants (Felin and Lakhani, 2018) }\end{array}$ & $\begin{array}{l}\text { BC has been so far applied, amongst } \\
\text { others, in the financial sector, logistics } \\
\text { and supply chain, health care, food } \\
\text { safety, art market and agriculture }\end{array}$ & Relief-recovery & $\begin{array}{r}\text { Table } 1 . \\
\text { Suitable emerging } \\
\text { technologies in the } \\
\text { DM field }\end{array}$ \\
\hline
\end{tabular}

definition of performance, the identification of related targets and the evaluation ex-post of the results obtained (Lebas, 1995; Ferreira and Otley, 2009).

Lastly, performance accountability is a broad concept which covers activities such as reporting performance, communicating the results achieved to stakeholders and the broader community and guaranteeing transparency (Roberts, 1991; Gray, 1992). It is a concept which 


\begin{tabular}{lll} 
MEDAR & & \\
\cline { 2 - 3 } 30,4 & "Criteria & Description \\
\cline { 2 - 3 } & Field of knowledge & Business, management and accounting \\
& Literature type & Research article \\
& Literature language & English \\
$\mathbf{1 0 9 8}$ & Period & 2000-2021 \\
& Search query & "emerging technolog*" OR "big data" OR "artificial \\
& & intelligence" OR "AI" OR "IoT" OR "Internet of Things" OR \\
& & "predictive analytics" OR "machine learning" OR "geospatial \\
Table 2. & data" OR "robotics and automation" OR "social media" OR \\
Search criteria & Screening I & "cloud computing" OR "quantum computing" OR "drones" \\
\hline
\end{tabular}

has been widely explored in the literature on both public and private sector organisations (Kassel, 2008; Kaur and Lodhia, 2019).

Because of increasingly complex changes in society and the environment, performance studies have rapidly evolved in recent decades. Whilst the first management scholars mainly focused on financial performance, today, the literature agrees that researchers should focus on different performance dimensions, such as social, competitive and environmental (Kaplan and Norton, 1996; Bititci et al., 2012; Khalid et al., 2019). Moreover, the evolution of the discipline has made scholars shift their focus to the inter-organisational level, as in the case of supply chains, strategic alliances or governance networks (Dekker, 2016; Nuti et al., 2018; Dell'Era et al., 2020; Ferrigno et al., 2021).

DM is amongst the fields of application of management which, more than others, present degrees of social complexity derived from a large set of stakeholders, multiple objectives and goals and the difficulty of measuring many of these because of the high uncertainty given by the unprecedented scenarios characterising every disaster (Comfort et al., 2004).

The introduction and adoption of ETs are of great support to researchers and practitioners as they cope with the complexities of measuring, managing and reporting performance. According to many authors, information and digital technologies are indeed pivotal to the design and implementation of performance management and accountability systems (Marr and Neely, 2001; Nudurupati and Bititci, 2005; Rodríguez-Bolívar et al., 2006; Buys, 2008; Marrone and Hazelton, 2019; Lombardi and Secundo, 2020).

New technologies may support performance in multiple ways. First, they assist in the measurement of performance (Nudurupati and Bititci, 2005; Cockcroft and Russell, 2018). Some technologies, such as big data or AI, allow managers to both have access to new sources of information and improve their ability to manage and analyse related data (Sardi et al., 2020). This may enable the creation of new measures and performance targets. As such, in the case of DM, decision-makers may have access to new forms of information coming from social networks, satellites or sensors.

The second pivotal contribution of ETs is related to the real-time availability of new information, which improves performance management processes (Marr and Neely, 2001; Nudurupati and Bititci, 2005). This is of particular interest in the response phase of DM. Having the possibility to promptly react based on real-time reliable information can make a difference in emergency contexts (Laituri and Kodrich, 2008; Ragini et al., 2018; Imran et al., 2020). 
Third, ETs as applied to performance have shown great potential for understanding concerns related to reporting and internal and external accountability (Marrone and Hazelton, 2019; Lombardi and Secundo, 2020). For example, new forms of data visualisation are being largely used to inform the community about the results achieved by the institutions in charge. What is peculiar in performance accountability in DM is its double directions, i.e. downward in an accountability to the other, in which the focus is on the intrinsic value of the suffering community, and upward in an accounting for itself, in which the focus is on market value (Sargiacomo et al., 2014).

In light of this theoretical premise, this paper aims at covering a potential gap in understanding how ETs impact on improving performance in DM processes and, concretely, their impact on the performance according to the different phases of the DM cycle (preparedness, response, recovery and mitigation).

\section{Data collection and methods}

To achieve the research aim, this study conducts an SLR to identify the impact of ETs on performance measurement, management and accountability (Kraus et al., 2020; Snyder, 2019). This methodology has already been applied both in relation to the applications of ETs (i.e. Martinez-Rojas et al., 2018) and to DM (i.e. Lettieri et al., 2009; Akter and Fosso Wamba, 2019).

An SLR is a systematic process aimed at defining the research question, identifying relevant studies and evaluating their features, quality and impact on the field. The last phase of an SLR summarises the findings qualitatively and/or quantitatively, reporting evidence to clarify what is and is not known with respect to the object of investigation (Denyer and Tranfield, 2009).

To ensure that the analysis conducted is transparent, auditable and replicable, the study uses an iterative process consisting of the following phases (Lombardi and Secundo, 2020; Dumay and Cai, 2015; Thorpe et al., 2005):

- definition of the research questions;

- development of the research protocol;

- identification of documents for analysis;

- development of a coding framework; and

- execution of in-depth analyses.

The first phase consisted of defining the research question of the study, which focuses on understanding how ETs contribute to improving DM processes. Consistent with the theme of the special issue, the research question is also explored from the perspective of the emerging issues related to the dimensions of performance and, more specifically, the impact of ETs in terms of management, measurement and accountability within the DM cycle.

In the second phase of the SLR, we define the research protocol to support evidencebased practices and ensure objectivity (Tranfield et al., 2003). In this phase, the focus of the study, the research strategy, the data sources and the inclusion/exclusion criteria used for the review are specified in accordance with the research question (Petticrew and Roberts, 2008). The background of this study has been created by adopting a wide perspective of analysis, selecting the most relevant articles in the business, management and accounting fields. Later on, we opted for a longitudinal study to collect literature from different scientific databases. 
MEDAR 30,4

The third phase aims to identify the papers to be added to the literature review, defining the research string to use. We managed to collect research articles via title-abstractkeyword field codes using Boolean operators (AND, OR) as connectors.

Following the parameters, the search strategy was applied in the business, management and accounting areas, referring to the Scopus and JCR lists. A description is reported in Table 2.

The search query was entered in the ISI Web of Knowledge, Scopus, EBSCO Host and ABI/INFORM (ProQuest) databases, and it allowed us to obtain a total of 101, 172, 184 and 280 articles, respectively, for a total of 737 articles. We first eliminated redundant and nonEnglish articles (Petticrew and Roberts, 2008), which were few and not very significant with respect to the research question. We also restricted the collection to scientific articles only (Zheng et al., 2020; Lombardi and Secundo, 2020) because during the review process, these papers were tested with high-quality standards; the purpose was to ensure the quality of knowledge they provided (Light and Pillemer, 1984).

The timeframe covered the period from 2000 to February 2021. Although few studies have devoted their attention to the potential capabilities and limitations of digital technologies in DM at the end of the last century (amongst others, Wallace and De Balogh, 1985; Waugh, 1995; Stephenson and Anderson, 1997; Barth and Arnold, 1999; ChengalurSmith et al., 1999), the choice of the period was made in light of the growing interest in ETs and their impact in society and the public sector starting from the early 2000s, as confirmed by the academic literature (Day and Schoemaker, 2000; Rotolo et al., 2015).

From a careful reading of the abstracts, we eliminated papers of a specific technical nature, in which the connection between ETs and DM was only mentioned but not developed. Double counting of papers was avoided by including only those that were different across the databases. These processes allowed us to obtain a valid sample of 127 articles. We checked through the full-text articles to further evaluate the quality and eligibility of the studies (Xiao and Watson, 2019). Carrying out a thorough reading of the papers, we selected those relevant to our research question, obtaining a final corpus of 69 papers (Figure 2).

Then, we defined the coding framework, selecting the following parameters: time of publication, distribution of papers amongst journals, author citations and keyword cooccurrence. In this phase, a double analysis was carried out on the final sample: descriptive analysis and clustering. The descriptive analysis aimed to highlight the main characteristics of the articles, indicating their number, evolution over time and distribution amongst journals.

Data analysis was conducted using VOSviewer software (Van Eck and Waltman, 2017). As in other descriptive bibliometric analyses (Secundo et al., 2020), we analysed keyword cooccurrence and document citations; then, we performed a cluster analysis to capture the focal points and connections between the main topics considered in our study.

We developed the co-occurrence analysis by selecting keywords as a single entity for analysis, as a meaningful description of an article's content (Lamboglia et al., 2020) and as an endpoint to add a paper with a minimum number of two occurrences of a keyword. Using this technique, we obtained a twofold visualisation - network and overlay.

The last phase of the SLR aims to carry out a critical and comprehensive analysis of the selected articles. Finally, we clustered the results using VOSviewer. The main findings derived from the SLR are reported in Section 4.

\section{Findings}

\subsection{Characteristics of sample selection}

As shown in Figure 3, the number of articles that investigate the relationship between ETs and DM in accordance with our research question was narrowed until 2016, with an average 
Articles included through the search query on selected databases

$$
(n=737)
$$

Duplicated articles removed

$(n=373)$

\section{Articles screened by title and abstract $(n$ = 364)}

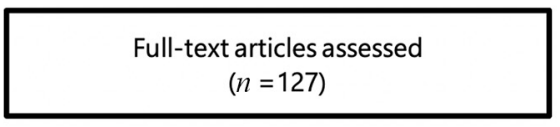

Full-text articles excluded with reasons $(n=58)$

\section{Final corpus of papers selected and analysed $(n=69)$}

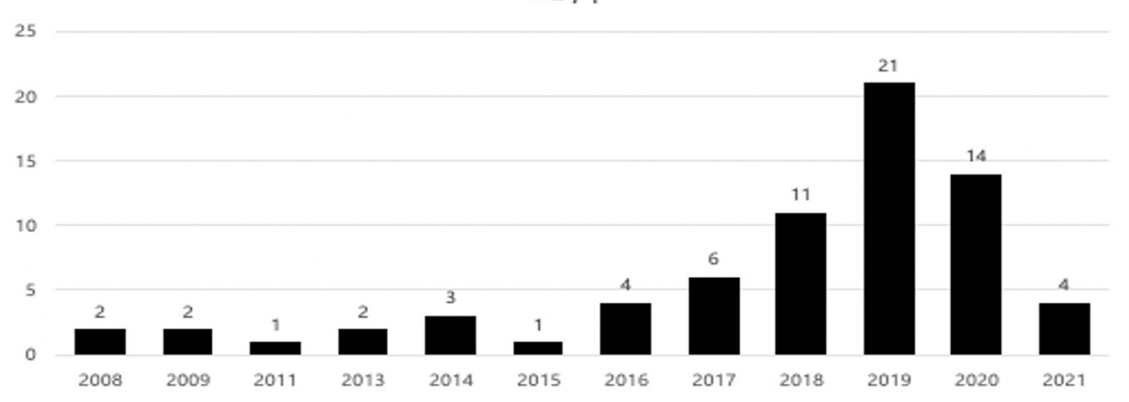

Figure 3. Documents per year

of three articles per year. The 2018-2020 period seems to be the most prolific, covering almost $65 \%$ of the total, with 2019 marking the highest number of publications per year (21).

The descriptive analysis indicates the source titles in which the topic of our research has been mainly discussed. The following table lists the journals with the highest number of published articles concerning the subject of our research question (Table 3).

Source citation indicates that the Journal of Cleaner Production is the source with the highest number of citations for a single article included in the sample (Papadopoulos et al., 2017), followed by Annals of Operation Research (185), International Journal of Production Economics (138) and Technological Forecasting and Social Change (129).

For article citation counting, we used the Scopus Field-Weighted Citation Impact to compare each paper citation with the average number of citations received by all similar documents over 
MEDAR 30,4

1102

a three-year window. This choice was assumed with the aim of maximising the relevance of our sample, refusing the adoption of an arbitrary cut-off point for citation counting (Keupp et al., 2012). This way, newer articles were not at a disadvantage compared with older ones. Table 4 lists the top 15 articles with the highest citations within the selected timeframe.

An analysis of documents by country shows that the USA has the highest number of both papers (20) and citations (785), followed by India (14 papers and 379 citations), the UK (13 papers and 632 citations) and France (9 papers and 452 citations). The table also shows the number of citations by source.

\subsection{Networking and clustering analysis}

Then, we used the VOSviewer algorithm (Van Eck and Waltman, 2014, 2017) to perform the cluster analysis starting from the co-occurrence analysis, which expresses the relatedness of items based on the number of documents in which they occur together. As explained before, our unit of analysis is author keywords, with a threshold of two keywords. We obtained a total of 37 keywords, which fell into four different clusters (Table 5 and Figure 4).

Our analysis includes the overlay visualisation, which is presented in Figure 5. Keywords in red colour refer to the more recent topics discussed in the academic debate on ETs in DM.

Source title

Article counts

Annals of Operations Research 7

International Journal of Emergency Management

6

Disaster Prevention and Management

Decision Support Systems

International Journal of Recent Technology and Engineering

Sustainability (Switzerland)

Table 3. $\quad$ Applied Geography

Top ten journals publishing papers

Information Processing and Management

International Journal of Production Economics

regarding DM

International Journal of Production Research

\begin{tabular}{lcc}
\hline Document & Citations & Publication year \\
\hline Papadopoulos et al. & 189 & 2017 \\
Yang et al. & 129 & 2013 \\
Ragini et al. & 85 & 2018 \\
Abidi et al. & 80 & 2014 \\
Dubey et al. & 69 & 2019 \\
Chowdury et al. & 69 & 2017 \\
Dubey et al. & 56 & 2018 \\
Shavarani & 42 & 2019 \\
Hung et al. & 42 & 2016 \\
Singh et al. & 37 & 2019 \\
Dubey et al. & 28 & 2020 \\
Zahra et al. & 23 & 2020 \\
Fan et al. & 13 & 2021 \\
Karami et al. & 8 & 2020 \\
Rodriguez-Espíndola et al. & 6 & 2020 \\
\hline
\end{tabular}




\begin{tabular}{|c|c|c|c|c|}
\hline Blue cluster & Red cluster & Green cluster & Yellow cluster & $\begin{array}{l}\text { isaster } \\
\text { rement }\end{array}$ \\
\hline $\begin{array}{l}\text { machine learning } \\
\text { data mining } \\
\text { sentiment analysis } \\
\text { social media } \\
\text { social media crowdsourcing } \\
\text { text classification } \\
\text { data analysis }\end{array}$ & $\begin{array}{l}\text { disaster management } \\
\text { disaster response } \\
\text { disaster recovery } \\
\text { emergency response } \\
\text { Drone } \\
\text { path planning } \\
\text { unmanned aerial vehicle }\end{array}$ & $\begin{array}{l}\text { emergency services } \\
\text { humanitarian operations } \\
\text { humanitarian supply chain } \\
\text { performance measurement } \\
\text { disaster } \\
\text { predictive analytics } \\
\text { blockchain }\end{array}$ & $\begin{array}{l}\text { simulation } \\
\text { decision support } \\
\text { risk management } \\
\text { resilience } \\
\text { artificial intelligence } \\
\text { deep learning }\end{array}$ & $\begin{array}{l}\text { and emerging } \\
\text { technologies }\end{array}$ \\
\hline natural disaster & $\begin{array}{l}\text { (UAV) } \\
\text { damage assessment } \\
\text { strategic values } \\
\text { Internet of Things } \\
\text { volunteered geographic } \\
\text { information (VGI) } \\
\text { geospatial data (GIS) }\end{array}$ & $\begin{array}{l}\text { big data } \\
\text { big data analytics } \\
\text { trust } \\
\text { confirmatory factor } \\
\text { analysis }\end{array}$ & & $\begin{array}{r}\text { Table } \mathbf{5 .} \\
\text { VOSviewer cluster } \\
\text { description }\end{array}$ \\
\hline
\end{tabular}

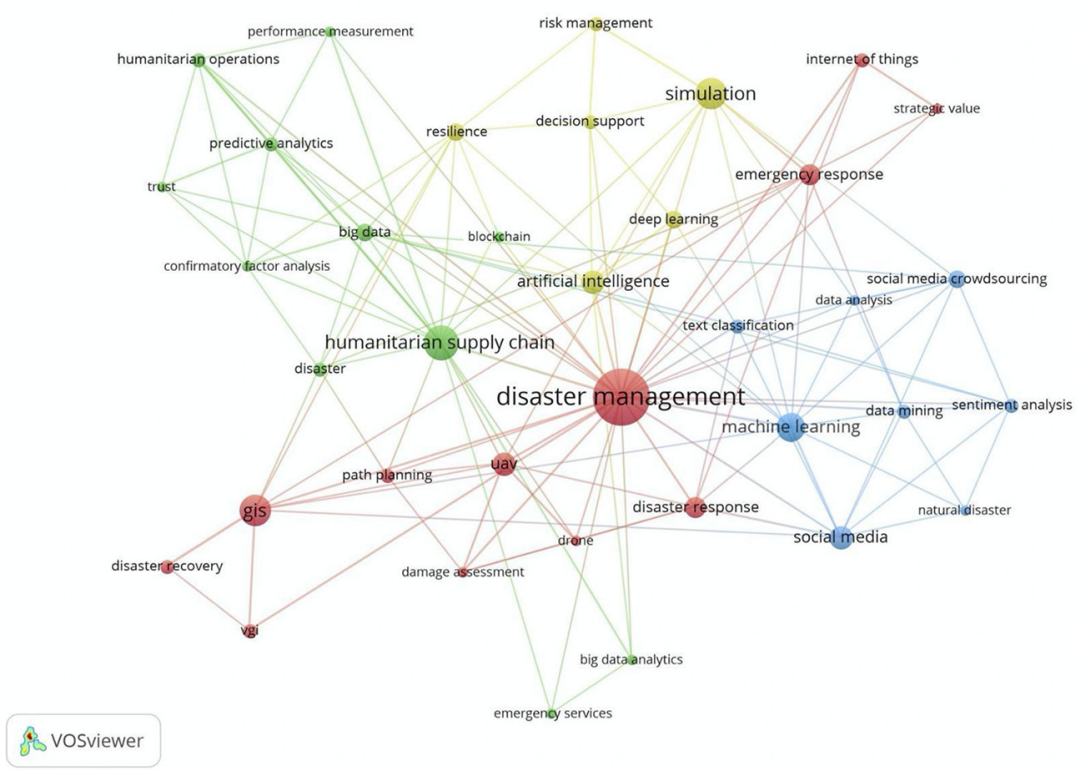

Figure 4. Network visualization

The following paragraph illustrates the findings of each cluster.

4.2.1 Yellow cluster. Papers included in the yellow cluster are mainly focused on the support that simulation approaches mainly provide to the preparedness phase of DM and to performance measurement.

In the broad management field, the value of simulation is highly recognised when experimentation in the real world is not feasible because of time, cost or ethical constraints (Davis et al., 2007; Sterman, 2014; Noto and Cosenz, 2021). These kinds of situations characterise the contexts in which DM operates. In fact, experimenting with a disaster in the real world is never feasible or acceptable. As such, simulated environments are the only way 
MEDAR

30,4

\section{4}

Figure 5.

Overlay visualization

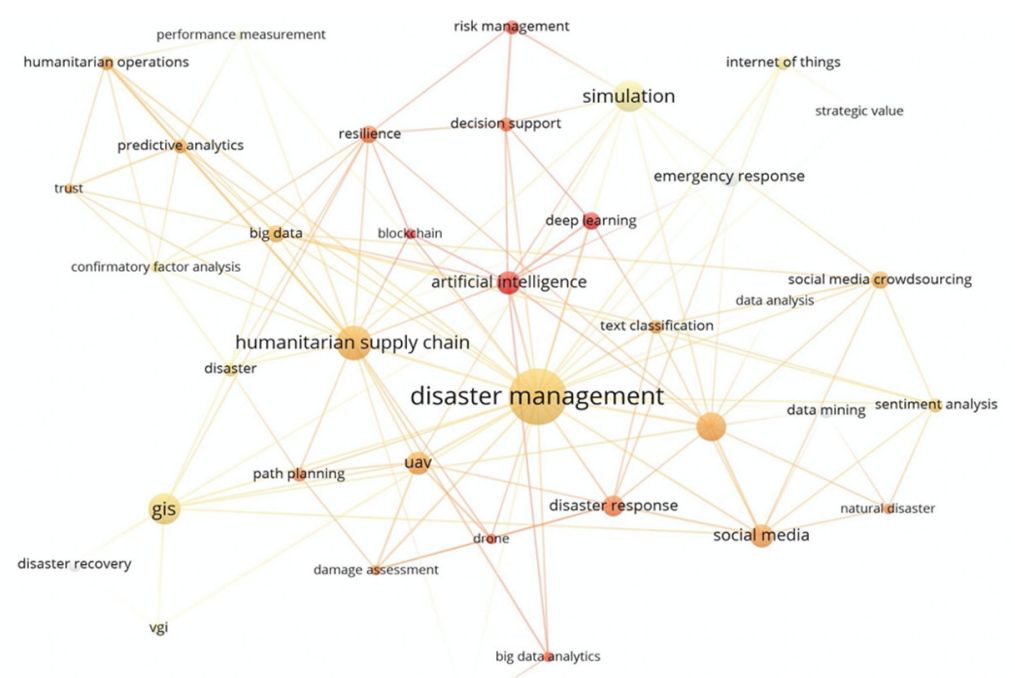

is vosviewer

emergency services

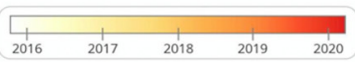

we can discover how DM works and where high leverage points may lie to foster performance.

Simulation in DM studies has been explored in depth by Mishra et al. (2019), who conducted a literature review of the key approaches adopted by scholars in the field. These authors focused on system dynamics (SD), Monte Carlo simulation (MCS), agent-based modelling $(\mathrm{ABM})$ and discrete event simulation (DES).

MCS has been mainly adopted for risk modelling, SD has been proposed as an effective tool for prevention. ABM has shown effectiveness in considering the behaviour of the multiple agents involved in the DM cycle. Less adopted, according to Mishra et al.'s (2019) study, was the DES, which is mainly used when modelling for large-scale disasters.

Whilst the literature on performance is already combined with simulation (Bianchi, 2016), with a few exceptions (Wang et al., 2020a, 2020b), the resulting frameworks have not been applied to DM studies. However, in the analysed articles, simulation is mainly examined from the performance point of view. For example, Gul et al. (2020) used DES to assess the preparedness of an emergency department during an earthquake by using length of stay and utilisation of medical staff as measures of performance. Sahebjamnia et al. (2017) used coverage, cost and response time as performance measures in a decision support system for managing humanitarian relief chains. Lee and Lee (2021) focused on disaster response performance in a multi-agent environment. Fan et al. (2021) emphasised how ETs, such as AI algorithms and deep learning architectures, significantly contribute to disaster preparedness at the city level where, through the combination of multiple sources of data (geospatial, sensors, social media, crowdsourcing) and the interactions amongst different entities, the inefficiencies induced by their complex relationships can be easily explored. Moreover, the authors pointed out how temporal information recorded in the Disaster City Digital Twin enables monitoring, analysing and predicting the dynamic structures of the networks involved and their potential effects on the efficiency of relief and response actions. 
In all the above-mentioned cases, scenario analysis through simulation was used to explore the preparedness and resilience of a specific system when dealing with different phases of the DM cycle by observing how the measures of performance identified may evolve under different environmental conditions.

4.2.2 Red cluster. Articles which fall into this cluster are mainly focused on the response phase of DM and provide interesting implications for what concern performance management. In light of our findings, the ETs which mostly support these phases are geospatial data (GIS), volunteered geographic information (VGI), IoT and robotics and automation (RA), such as drones and chatbots. Some scholars clearly described the complementary role of GIS and VGI in the provision of information, which can be helpful in coordinating response tasks amongst volunteer groups and official disaster agencies (Hung et al., 2016; Contreras et al., 2016; Schumann, 2018; Akter and Fosso Wamba, 2019; Sharma et al., 2020). Other studies have shown the main challenges (digital divide, lack of resources, poor data quality) associated with their use in emergency response contexts (Haworth, 2016).

RA are effective tools for relief and response operations. To date, unmanned aerial vehicles (UAVs), which are a subcategory of RA, have been used in response to a wide range of disasters that have occurred in the last decade (Chowdhury et al., 2017; Kim et al., 2018), providing valuable support in searching the victims, mapping the affected zones, making structural inspections, estimating debris and assessing damage.

More recently, UAVs have become of key relevance in supplying emergency commodities in disaster-affected regions. In this regard, some scholars (Bravo et al., 2019; Zwęgliński, 2020) stressed the impact of RA technologies in minimising the time and costs of disaster relief operations.

A further ET used in both the response and recovery phases of DM is IoT (Shahat et al., 2020), which enables accurate and real-time accountability of resources and personnel allocated to emergency response operations.

Sinha et al. (2019) showed the role of IoT-based solutions in catering to the task requirements of the personnel involved in DM, specifically rescue operations. A critical aspect here is improper resource allocation, which slows down recovery efforts.

Performance measurement seems the main concern of the articles which fall into the red cluster. KPIs are mainly used to calculate the extent to which ETs might reduce time, distance covered, number of lives saved and relief provided. To some extent, ETs enhance the level of accountability of response operations, coping with the lack of visibility of resources available on the disaster scene or dispatched to other places prior to the event (Yang et al., 2013).

4.2.3 Blue cluster. This cluster introduced an interesting topic concerning the contribution of data mining, machine learning and social media to performance measurement, management and accountability during disaster events. Data mining and machine learning algorithms are widely recognised tools to support decision making in many areas and, more specifically, along the DM cycle (Zagorecki et al., 2013).

Machine learning is an umbrella term which sometimes overlaps with other concepts and applications, i.e. deep learning and AI. In any case, our findings show the high relatedness of this ET to the whole DM cycle, specifically to the emergency response phase (Chaudhuri and Bose, 2020).

The key role of social media in DM has been widely recognised in the literature (Xiao et al., 2015). User generated content (UGC) from disaster-affected areas provides valuable information for emergency response when dealing with DM, as stated by Han et al. (2019). Nevertheless, this study points out the nature of UGC, which is huge, disordered and 
MEDAR

30,4

1106

continuous. As a consequence, its exploitation has a direct impact on the effectiveness of response actions during disaster events.

On the one hand, the huge amount of data generated by social media - Twitter, Facebook, TikTok and other platforms - provides a big picture of the ongoing disaster situation in terms of location, temporal sequence and entity-related information (Hoang and Mothe, 2018; Singh et al., 2019). On the other hand, the effective use of these tools raises critical issues in terms of text classification, data selection and validation, which are relevant when dealing with unpredictable and catastrophic events. More recently, sentiment analysis, topic modelling and other natural language processing tools have become promising techniques for assessing the reliability and accuracy of data gathered from social media during disasters (Thekdi and Chatterjee, 2019; Karami et al., 2020). These ETs enable situational awareness in disaster response (Li et al., 2018), especially through the analysis of crowdsourced data provided by the eyewitnesses of disaster events (Zahra et al., 2020). From a performance-based view, it can be argued that the aforementioned ETs mainly support performance measurement through the real-time data gathered from social media. This result is coherent with our theoretical background. Moreover, social media are largely used by local and national authorities, as they show great potential for improving efficiency and widening the audience of information systems during disasters and for enhancing relations (e.g. improved transparency and accountability) between governments and the community affected by the event (Wehn and Evers, 2015).

4.2.4 Green cluster. The last cluster obtained from our bibliometric analysis consists of papers which focus on the post-disaster phase (i.e. recovery and mitigation), namely, the humanitarian relief and the related humanitarian supply chain (HSC) logistics. In this regard, the ETs linked with this phase mainly impact on performance management and accountability.

As is well known, humanitarian logistics refers to the mobilisation and management of resources (human and material) through which support for post-disaster response and rehabilitation operations is provided.

HSC management is crucial for the efficiency and effectiveness of DM systems. As observed by Rodríguez-Espíndola et al. (2020), the "duplication of efforts for data input, multiple formats, lack of control of budgets, absence of accountability, lack of integrity in procurement procedures, absence of a central database, and manual reporting and tracking" affect current DM systems.

The adoption of ETs, such as big data and predictive analytics (BDPA), provides valuable support to overcome the limitations in disaster relief operations. Indeed, scholars agree on the contribution that BDPA can offer when dealing with disasters (Ragini et al., 2018). Akter and Fosso Wamba (2019) highlighted how BDPA can help address various challenges by providing critical recovery services in disasters. Considering the main properties of $\mathrm{BD}$, such as volume (referring to the amount of data), velocity (referring to the frequency or speed by which data are generated and delivered), veracity (referring to data quality) and value (referring to the benefits from the analysis and use of big data), many authors have underlined how these help improve the visibility, coordination and sustainability of the HSC after a disaster (Papadopoulos et al., 2017; Dubey et al., 2018; Dubey et al., 2019; Jeble et al., 2019).

The subset of articles which fall into the green cluster gives relevance to some aspects related to both performance management and measurement. Abidi et al. (2014) analysed the state of the art of performance measurement, management and accountability in HSC. They pointed out some factors that determine reluctance to implement performance measurement 
in the humanitarian sector, such as a short-term perspective of disaster response actions, limited IT capacity and infrastructure and a chaotic environment.

Other scholars have underlined how ETs have enabled officials and non-government organisations involved in disaster relief and rehabilitation operations to reduce information asymmetry (Dubey et al., 2018) and address the lack of trust amongst agents, volunteers and the affected community using blockchain technology (Dubey et al., 2020); this has a critical role in enhancing collaboration and quickly building trust amongst various actors engaged in disaster relief operations.

\section{Discussion and conclusions}

This paper has sought to analyse how ETs impact on improving performance in DM processes, using a SLR as methodology of research and visualizing this impact with the VOSviewer software. The selected articles included in this review use different methodologies and focus on different phases of disasters, technologies and performance perspectives.

In many cases, we observed an inconsistent use of terms. This mainly happens in relation to the DM cycle. As mentioned in the theoretical background, DM can be framed into four phases: mitigation, preparedness, response and recovery. Many of the studies analysed, although focusing on specific phases, broadly refer to DM. This lack of specification poses challenges in the analysis and identification of the relationships between ETs and the DM phases. In some cases, DM is even used as a synonym for emergency management, resulting in a lack of clarity and confusion in the discipline. It is evident that ETs largely contribute to the management of disasters in each phase.

The complexity of DM often makes researchers and practitioners combine different technologies to improve the performance measurement, management and accountability of related activities. Although ETs may all be applied and successfully contribute to the different phases of the DM cycle, our analysis highlights some stronger linkages between some technologies, or features, and specific DM phases.

Many of the technologies considered rely on simulation features, which can be considered as a transversal tool supporting decision-makers at different levels in assessing the preparedness and resilience of a certain system prior to the occurrence of a natural disaster. Simulation enables experimentation with the consequences of a potential disaster in a virtual environment. This experimentation allows us to embrace the disaster risk reduction logic required to effectively tackle natural disasters. As such, simulation could be a valuable tool to improve preparedness. A simulated environment may foster the comprehension of the complex relationships characterizing disasters ex ante; thus, it may support the definition of consistent performance measures applicable to the preparedness phase.

Robotics and IoT are often associated with the improvement of operations in the response phase. ETs, such as drones or sensors, allow people to run activities that are not accessible to humans during disasters. These are valuable tools to monitor and manage performance during the response phases of the DM cycle.

Social media and related analytics tools have been widely used in two ways. On the one hand, they allow decision-makers to have access to a wider range of data sources (e.g. citizens, service users and other people involved in disasters) and to analyse this information through algorithms, such as topic modelling or sentiment analysis; this contribution is thus highly related to performance measurement. On the other hand, such tools foster performance accountability and disclosure towards the community. 
MEDAR 30,4

1108
In the following table, we highlighted the links between the performance perspectives here considered (measurement, management and accountability) and the main ETs identified by our review of the literature on DM (Table 6).

As emerges from the table above, all these ETs are key to the decision support systems in every DM phase as also emerged from the reviewed papers. However, it is evident that the ability to process the data obtained and to verify their reliability and quality requires much effort. This aspect is probably linked to the lack of performance-related aspects in many of the papers analysed here. In fact, although many of the papers in our sample focus on performance, few of them embrace a theoretical framework based on performance measurement, management or accountability.

In this paper, we attempted to frame existing literature on DM and ETs according to a performance-based perspective to orient future studies and to highlight how and which ET contributes to the different phases of DM cycle.

As a result of this literature review, it emerges that prior research has put emphasis on the usefulness of ETs for preventing and managing disasters as well as to provide channels for reducing the harmful consequences of these disasters. Our systematization of previous literature results may have important implications both for theory and practice. At the theoretical level, the paper provides a framework that links the key performance perspectives and DM phases with the implementation of ETs in the DM field; such a framework may represent a useful reference for studies aimed at deepening related aspect. Moreover, the study highlights that simulation and simulation-based tools allow scholars to explore and test the development of new theories and solutions to analyse performance in DM contexts (Davis et al., 2007; Mishra et al., 2019). At the practical level, the research suggests to the key involved actors (i.e. public administration, emergency managers, civil protection, experts and other stakeholders) to improve DM performance: analysing the importance of simulation tools to assess their preparedness; examining the ETs successfully used in the different DM phases (thus showing them how to invest in technologies); studying the importance to promote and enable citizens involvement as a new powerful source of data; and examining the need to invest in technologies to improve the ability to process, understand and use for decision-making purposes such data.

Despite its contributions, such as shedding light on the current state of the literature and providing future research directions about the theme addressed, this paper also has some limitations. Although frequently used in SLR, the criteria used to select our source of information - i.e. the exclusive focus on business, management and accounting categories;

Performance perspectives

Emerging technologies

Measurement

Simulation tools

Big Data Analytics

Artificial intelligence

Social media

Management

Robotics and automation

Remote sensing

Internet of Things

Artificial intelligence

Table 6.

Linking PM and ETs Accountability

Big Data analytics

Geospatial data

Social media

Blockchain 
the exclusive focus on scientific articles in English language - may have excluded some valuable contributions. Future research could thus compare our results with other sources of information such as books and grey literature. Moreover, consistently with prior research, we have mainly analysed the implementation of ETs as "isolated islands." Nonetheless, future research could analyse integration processes of these ETs for managing all disasters in an efficient manner.

Finally, the study did not consider the question of technological acceptance by the users of the technologies. Verifying whether specific technologies or certain phases of the DM cycle are associated with greater reluctance on users' side could be interesting.

\section{Notes}

1. Centre for Research on the Epidemiology of Disasters - CRED. School of Public Health Université Catholique de Louvain.

2. www.undrr.org/terminology/disaster\#: :text $=\mathrm{A} \% 20$ serious $\% 20$ disruption $\% 20$ of $\% 20$ the,and $\%$ 20environmental\%201osses \%20and\%20impacts. Accessed on 1 February 2021.

\section{References}

Abidi, H., De Leeuw, S. and Klumpp, M. (2014), "Humanitarian supply chain performance management: a systematic literature review”, Supply Chain Management: An International Journal, Vol. 19 Nos 5/6, pp. 592-608.

Adger, W.N. (2006), "Vulnerability”, Global Environmental Change, Vol. 16 No. 3, pp. 268-281.

Akter, S. and Fosso Wamba, S. (2019), "Big data and disaster management: a systematic review and agenda for future research", Annals of Operations Research, Vol. 283 Nos 1/2, pp. 939-959.

Alexander, D. (1997), "The study of natural disasters, 1977-97: some reflections on a changing field of knowledge", Disasters, Vol. 21 No. 4, pp. 284-304.

Alexander, D.E. (2014), "Social media in disaster risk reduction and crisis management", Science and Engineering Ethics, Vol. 20 No. 3, pp. 717-733.

Ansell, C., Boin, A. and Keller, A. (2010), "Managing transboundary crises: identifying the building blocks of an effective response system", Journal of Contingencies and Crisis Management, Vol. 18 No. 4, pp. 195-207.

Barcevičius, E., Cibaitè, G., Codagnone, C., Gineikyte, V., Klimavičiūtè, L., Liva, G., ... and Vanini, I. (2019), "Exploring digital government transformation in the EU-analysis of the state of the art and review of literature," Publications Office of the European Union, JRC118857.

Barth, T.J. and Arnold, E. (1999), "Artificial intelligence and administrative discretion: implications for public administration”, The American Review of Public Administration, Vol. 29 No. 4, pp. 332-351.

Berg, M. and De Majo, V. (2017), "Understanding the global strategy for disaster risk reduction”, Risk, Hazards and Crisis in Public Policy, Vol. 8 No. 2, pp. 147-167.

Bianchi, C. (2016), Dynamic Performance Management, Springer, Berlin Vol. 1.

Bititci, U., Garengo, P., Dörfler, V. and Nudurupati, S. (2012), "Performance measurement: challenges for tomorrow", International Journal of Management Reviews, Vol. 14 No. 3, pp. 305-327.

Boin, A., Ekengren, M. and Rhinard, M. (2013), The European Union as Crisis Manager: Patterns and Prospects, Cambridge University Press, Cambridge.

Bonsón, E. and Bednárová, M. (2019), "Blockchain and its implications for accounting and auditing", Meditari Accountancy Research, Vol. 27 No. 5, pp. 725-740.

Boon, W. and Moors, E. (2008), "Exploring emerging technologies using metaphors - a study of orphan drugs and pharmacogenomics", Social Science and Medicine, Vol. 66 No. 9, pp. 1915-1927. 
MEDAR 30,4

Bravo, R.Z.B., Leiras, A. and Cyrino Oliveira, F.L. (2019), "The use of UAV s in humanitarian relief: an application of POMDP-based methodology for finding victims", Production and Operations Management, Vol. 28 No. 2, pp. 421-440.

Buckle, P. (2005), "Disaster: mandated definitions, local knowledge and complexity", in Perry, R.W. and Quarantelli, E.L. (Eds), What is a Disaster? New Answers to Old Questions, Xlibris. Philadelphia, PA, pp. 173-200.

Buys, P.W. (2008), "The impact of XBRL on the financial reporting supply chain: a South African case study", Meditari Accountancy Research, Vol. 16 No. 1, pp. $43-58$.

Carreño, M.L., Cardona, O.D. and Barbat, A.H. (2007), "A disaster risk management performance index", Natural Hazards, Vol. 41 No. 1, pp. 1-20.

Chatterjee, S., Chaudhuri, R., Vrontis, D. and Basile, G. (2021), "Digital transformation and entrepreneurship process in SMEs of India: a moderating role of adoption of AI-CRM capability and strategic planning", Journal of Strategy and Management.

Chaudhuri, N. and Bose, I. (2020), "Exploring the role of deep neural networks for post-disaster decision support”, Decision Support Systems, Vol. 130, p. 113234.

Chengalur-Smith, I., Belardo, S. and Pazer, H. (1999), “Adopting a disaster-management-based contingency model to the problem of ad hoc forecasting: toward information technology-based strategies", IEEE Transactions on Engineering Management, Vol. 46 No. 2, pp. 210-220.

Chhabra, D., Singh, R.K. and Kumar, V. (2021), "Developing IT-enabled performance monitoring system for green logistics: a case study", International Joumal of Productivity and Performance Management.

Chowdhury, S., Emelogu, A., Marufuzzaman, M., Nurre, S.G. and Bian, L. (2017), "Drones for disaster response and relief operations: a continuous approximation model", International Journal of Production Economics, Vol. 188, pp. 167-184.

Cockcroft, S. and Russell, M. (2018), "Big data opportunities for accounting and finance practice and research", Australian Accounting Review, Vol. 28 No. 3, pp. 323-333.

Comfort, L.K., Dunn, M., Johnson, D., Skertich, R. and Zagorecki, A. (2004), "Coordination in complex systems: increasing efficiency in disaster mitigation and response", International Journal of Emergency Management, Vol. 2 Nos 1/2, pp. 62-80.

Comfort, L.K., Waugh, W. and Cigler, B.A. (2012), "Emergency management research and practice in public administration: emergency, evolution, expansion, and future directions", Public Administration Review, Vol. 72 No. 4, pp. 539-547.

Contreras, D., Blaschke, T., Tiede, D. and Jilge, M. (2016), "Monitoring recovery after earthquakes through the integration of remote sensing, GIS, and ground observations: the case of L'Aquila (Italy)", Cartography and Geographic Information Science, Vol. 43 No. 2, pp. 115-133.

Cutter, S.L. (1996), "Vulnerability to environmental hazards", Progress in Human Geography, Vol. 20 No. 4, pp. 529-539.

Davenport, T.H. and Ronanki, R. (2018). "Artificial intelligence for the real world”, Harvard Business Review, Vol. 96 No. 1, pp. 108-116.

Davis, J.P., Eisenhardt, K.M. and Bingham, C.B. (2007), "Developing theory through simulation methods", Academy of Management Review, Vol. 32 No. 2, pp. 480-499.

Day, G.S. and Schoemaker, P.J. (2000), "Avoiding the pitfalls of emerging technologies", California Management Review, Vol. 42 No. 2, pp. 8-33.

De Santis, F. and D’Onza, G. (2021), "Big data and data analytics in auditing: in search of legitimacy", Meditari Accountancy Research.

Dekker, H.C. (2016), "On the boundaries between intrafirm and interfirm management accounting research", Management Accounting Research, Vol. 31, pp. 86-99.

Dell'Era, C., Di Minin, A., Ferrigno, G., Frattini, F., Landoni, P. and Verganti, R. (2020), "Value capture in open innovation processes with radical circles: a qualitative analysis of firms' collaborations 
with slow food, Memphis, and free software foundation", Technological Forecasting and Social Change, Vol. 158, p. 120128.

Demiroz, F. and Haase, T.W. (2019), "The concept of resilience: a bibliometric analysis of the emergency and disaster management literature”, Local Government Studies, Vol. 45 No. 3, pp. 308-327.

Denyer, D. and Tranfield, D. (2009), "Producing a systematic review", in Buchanan, D.A. and Bryman, A. (Eds), The Sage Handbook of Organizational Research Methods, Sage, Los Angeles, CA, pp. 671-689.

Dubey, R., Luo, Z., Gunasekaran, A., Akter, S., Hazen, B.T. and Douglas, M.A. (2018), "Big data and predictive analytics in humanitarian supply chains", The International Journal of Logistics Management, Vol. 29 No. 2, pp. 485-512.

Dubey, R., Gunasekaran, A., Childe, S.J., Roubaud, D., Fosso Wamba, S. and Foropon, C. (2019), "Big data analytics and organizational culture as complements to swift trust and collaborative performance in the humanitarian supply chain", International Journal of Production Economics, Vol. 210, pp. 120-136.

Dubey, R., Gunasekaran, A., Bryde, D.J., Dwivedi, Y.K. and Papadopoulos, T. (2020), "Blockchain technology for enhancing swift-trust, collaboration and resilience within a humanitarian supply chain setting", International Journal of Production Research, Vol. 58 No. 11, pp. 3381-3398.

Dumay, J. and Cai, L. (2015), "Using content analysis as a research methodology for investigating intellectual capital disclosure”, Journal of Intellectual Capital, Vol. 16 No. 1, pp. 121-155.

Eccles, R.G. (1991), “The performance measurement manifesto", Harvard Business Review, Vol. 69 No. 1, pp. 131-137.

Fajardo, J.T.B. and Oppus, C.M. (2010), "A mobile disaster management system using the android technology", WSEAS Transactions on Communications, Vol. 9 No. 6, pp. 343-353.

Fan, C., Zhang, C., Yahja, A. and Mostafavi, A. (2021), "Disaster city digital twin: a vision for integrating artificial and human intelligence for disaster management”, International Journal of Information Management, Vol. 56, p. 102049.

Faulkner, B. (2001), “Towards a framework for tourism disaster management”, Tourism Management, Vol. 22 No. 2, pp. 135-147.

Ferreira, A. and Otley, D. (2009), "The design and use of performance management systems: an extended framework for analysis", Management Accounting Research, Vol. 20 No. 4, pp. 263-282.

Ferrigno, G. and Cucino, V. (2021), "Innovating and transforming during COVID-19. Insights from Italian firms", R\&D Management, In Press.

Ferrigno, G., Dagnino, G.B. and Di Paola, N. (2021), "R\&D alliance partner attributes and innovation performance: a fuzzy set qualitative comparative analysis", Journal of Business and Industrial Marketing, Vol. 36 No. 13.

Gilbert, C. (1998), "Studying disaster: changes in the main conceptual tools", Quarantelli, E.L. (Ed.), What is a Disaster? Perspectives on the Question, Routledge, New York, NY, pp. 11-18.

Gray, R. (1992), "Accounting and environmentalism: an exploration of the challenge of gently accounting for accountability, transparency and sustainability", Accounting, Organizations and Society, Vol. 17 No. 5, pp. 399-425.

Gul, M., Fuat Guneri, A. and Gunal, M.M. (2020), "Emergency department network under disaster conditions: the case of possible major Istanbul earthquake", Journal of the Operational Research Society, Vol. 71 No. 5, pp. 733-747.

Halaweh, M. (2013), "Emerging technology: what is it", Journal of Technology Management and Innovation, Vol. 8 No. 3, pp. 108-115.

Han, S., Huang, H., Luo, Z. and Foropon, C. (2019), "Harnessing the power of crowdsourcing and internet of things in disaster response", Annals of Operations Research, Vol. 283 Nos 1/2, pp. $1175-1190$. 
MEDAR 30,4

Harrison, S.E. and Johnson, P.A. (2016), "Crowdsourcing the disaster management cycle", International Journal of Information Systems for Crisis Response and Management (IJISCRAM), Vol. 8 No. 4 , pp. 17-40.

Haworth, B. (2016), "Emergency management perspectives on volunteered geographic information: opportunities, challenges and change", Computers, Environment and Urban Systems, Vol. 57, pp. 189-198.

Head, B.W. and Alford, J. (2015), "Wicked problems: implications for public policy and management", Administration and Society, Vol. 47 No. 6, pp. 711-739.

Hoang, T.B.N. and Mothe, J. (2018), "Location extraction from tweets", Information Processing and Management, Vol. 54 No. 2, pp. 129-144.

Hudson, M., Smart, A. and Bourne, M. (2001), "Theory and practice in SME performance measurement systems", International Journal of Operations \& Production Management, Vol. 21 No. 8, pp. 1096-1115.

Hung, K.C., Kalantari, M. and Rajabifard, A. (2016), "Methods for assessing the credibility of volunteered geographic information in flood response: a case study in Brisbane, Australia", Applied Geography, Vol. 68, pp. 37-47.

Imran, M., Ofli, F., Caragea, D. and Torralba, A. (2020), "Using AI and social media multimodal content for disaster response and management: opportunities, challenges, and future directions", Information Processing and Management, Vol. 57 No. 5, p. 102261.

Inan, D.I., Beydoun, G. and Pradhan, B. (2018), "Developing a decision support system for disaster management: case study of an indonesia volcano eruption", International Journal of Disaster Risk Reduction, Vol. 31, pp. 711-721.

Ivanov, D., Dolgui, A. and Sokolov, B. (2019), "The impact of digital technology and industry 4.0 on the ripple effect and supply chain risk analytics", International Journal of Production Research, Vol. 57 No. 3, pp. 829-846.

Jeble, S., Kumari, S., Venkatesh, V.G. and Singh, M. (2019), "Influence of big data and predictive analytics and social capital on performance of humanitarian supply chain", Benchmarking: An International Journal, Vol. 27 No. 2, pp. 606-633.

Jun, W., Nasir, M.H., Yousaf, Z., Khattak, A., Yasir, M., Javed, A. and Shirazi, S.H. (2021), "Innovation performance in digital economy: does digital platform capability, improvisation capability and organizational readiness really matter?", European Journal of Innovation Management.

Kankanamge, N., Yigitcanlar, T., Goonetilleke, A. and Kamruzzaman, M. (2019), "Can volunteer crowdsourcing reduce disaster risk? A systematic review of the literature", International Journal of Disaster Risk Reduction, Vol. 35, p. 101097.

Kaplan, R.S. and Norton, D.P. (1996), "Using the balanced scorecard as a strategic management system”, Harvard Business Review, pp. 75-85.

Kapucu, N. and Garayev, V. (2016), "Structure and network performance: horizontal and vertical networks in emergency management”, Administration and Society, Vol. 48 No. 8, pp. 931-961.

Kapucu, N. and Van Wart, M. (2008), "Making matters worse: an anatomy of leadership failures in managing catastrophic events", Administration and Society, Vol. 40 No. 7, pp. 711-740.

Karami, A., Shah, V., Vaezi, R. and Bansal, A. (2020), "Twitter speaks: a case of national disaster situational awareness”, Journal of Information Science, Vol. 46 No. 3, pp. 313-324.

Kassel, D.S. (2008), "Performance, accountability, and the debate over rules", Public Administration Review, Vol. 68 No. 2, pp. 241-252.

Kaur, A. and Lodhia, S.K. (2019), "Sustainability accounting, accountability and reporting in the public sector: an overview and suggestions for future research", Meditari Accountancy Research, Vol. 27 No. 4, pp. 498-504. 
Keupp, M.M., Palmié, M. and Gassmann, O. (2012), "The strategic management of innovation: a systematic review and paths for future research", International Journal of Management Reviews, Vol. 14 No. 4, pp. 367-390.

Khalid, S., Beattie, C., Sands, J. and Hampson, V. (2019), "Incorporating the environmental dimension into the balanced scorecard: a case study in health care", Meditari Accountancy Research, Vol. 27 No. 4, pp. 652-674.

Kim, Y.D., Son, G.J., Kim, H., Song, C. and Lee, J.H. (2018), "Smart disaster response in vehicular tunnels: technologies for search and rescue applications", Sustainability, Vol. 10 No. 7, p. 2509.

Kitagawa, K. (2021), "Disaster risk reduction activities as learning”, Natural Hazards, Vol. 105 No. 3, pp. 3099-3118.

Kraus, S., Breier, M. and Dasí-Rodríguez, S. (2020), "The art of crafting a systematic literature review in entrepreneurship research", International Entrepreneurship and Management Journal, Vol. 16 No. 3, pp. 1-20.

Kuipers, S., Boin, A., Bossong, R. and Hegemann, H. (2015), "Building joint crisis management capacity? Comparing civil security systems in 22 European countries”, Risk, Hazards and Crisis in Public Policy, Vol. 6 No. 1, pp. 1-21.

Lai, A., Leoni, G. and Stacchezzini, R. (2014), "The socializing effects of accounting in flood recovery", Critical Perspectives on Accounting, Vol. 25 No. 7, pp. 579-603.

Laituri, M. and Kodrich, K. (2008), "Online disaster response community: people as sensors of high magnitude disasters using internet GIS”, Sensors, Vol. 8 No. 5, pp. 3037-3055.

Lamboglia, R., Lavorato, D., Scornavacca, E. and Za, S. (2020), "Exploring the relationship between audit and technology. A bibliometric analysis", Meditari Accountancy Research.

Lebas, M.J. (1995), "Performance measurement and performance management", International Journal of Production Economics, Vol. 41 Nos 1/3, pp. 23-35.

Lee, H.R. and Lee, T. (2021), "Multi-agent reinforcement learning algorithm to solve a partiallyobservable multi-agent problem in disaster response", European Journal of Operational Research, Vol. 291 No. 1, pp. 296-308.

Lettieri, E., Masella, C. and Radaelli, G. (2009), "Disaster management: findings from a systematic review", Disaster Prevention and Management: An International Journal, Vol. 18 No. 2, pp. 117-136.

Li, H., Caragea, D., Caragea, C. and Herndon, N. (2018), "Disaster response aided by tweet classification with a domain adaptation approach", Journal of Contingencies and Crisis Management, Vol. 26 No. 1, pp. 16-27.

Light, R. and Pillemer, D. (1984), Summing up: The Science of Reviewing Research, Harvard University Press. Cambridge, MA.

Lombardi, R. and Secundo, G. (2020), "The digital transformation of corporate reporting-a systematic literature review and avenues for future research", Meditari Accountancy Research.

Lombardi, R., de Villiers, C., Moscariello, N. and Pizzo, M. (2021), "The disruption of blockchain in auditing - a systematic literature review and an agenda for future research", Accounting, Auditing and Accountability Journal.

McEntire, D.A. (2005), "Why vulnerability matters: exploring the merit of an inclusive disaster reduction concept", Disaster Prevention and Management: An International Journal, Vol. 14 No. 2, pp. 206-222.

Manyena, S.B. (2006), “The concept of resilience revisited”, Disasters, Vol. 30 No. 4, pp. 434-450.

Marr, B. and Neely, A. (2001), "Organisational performance measurement in the emerging digital age", International Journal of Business Performance Management, Vol. 3 Nos 2/3/4, pp. 191-215.

Marrone, M. and Hazelton, J. (2019), "The disruptive and transformative potential of new technologies for accounting, accountants and accountability", Meditari Accountancy Research, Vol. 27 No. 5, pp. 677-694. 
MEDAR 30,4

Martinez-Rojas, M., del Carmen Pardo-Ferreira, M. and Rubio-Romero, J.C. (2018), “Twitter as a tool for the management and analysis of emergency situations: a systematic literature review", International Journal of Information Management, Vol. 43, pp. 196-208.

Mishra, D., Kumar, S. and Hassini, E. (2019), "Current trends in disaster management simulation modelling research", Annals of Operations Research, Vol. 283 Nos 1/2, pp. 1387-1411.

Moynihan, D.P. (2008), "Learning under uncertainty: Networks in crisis management", Public Administration Review, Vol. 68 No. 2, pp. 350-365.

Ndou, V., Secundo, G., Dumay, J. and Gjevori, E. (2018), "Understanding intellectual Capital disclosure in online media big data: an exploratory case study in a university", Meditari Accountancy Research, Vol. 26 No. 3, pp. 499-530.

Noto, G. and Cosenz, F. (2021), "Introducing a strategic perspective in lean thinking applications through system dynamics modelling: the dynamic value stream map", Business Process Management Journal, Vol. 27 No. 1, pp. 306-327.

Nudurupati, S.S. and Bititci, U.S. (2005), "Implementation and impact of IT-supported performance measurement systems", Production Planning and Control, Vol. 16 No. 2, pp. 152-162.

Nuti, S., Noto, G., Vola, F. and Vainieri, M. (2018), "Let's play the patients music: a new generation of performance measurement systems in healthcare", Management Decision, Vol. 56 No. 10, pp. 2252-2272.

Oktari, R.S., Munadi, K. and Idroes, R. (2020), "Knowledge management practices in disaster management: systematic review", International Journal of Disaster Risk Reduction.

Oliver, J.J. (2018), "Strategic transformations in a disruptive digital environment", Strategic Direction, Vol. 34 No. 5, pp. 5-8.

Papadopoulos, T., Gunasekaran, A., Dubey, R., Altay, N., Childe, S.J. and Fosso-Wamba, S. (2017), “The role of big data in explaining disaster resilience in supply chains for sustainability", Journal of Cleaner Production, Vol. 142, pp. 1108-1118.

Pearce, L. (2003), "Disaster management and community planning, and public participation: how to achieve sustainable hazard mitigation”, Natural Hazards, Vol. 28 Nos 2/3, pp. 211-228.

Perkiss, S. and Moerman, L. (2020), "Hurricane Katrina: exploring justice and fairness as a sociology of common good(s)", Critical Perspectives on Accounting, Vols 67/68, p. 102022.

Perry, R.W. (1998), "Definitions and the development of a theoretical superstructure for disaster research", in Quarantelli, E.L. (Ed.), What is a Disaster? Perspectives on the Question, Routledge, New York, NY, pp. 197-215.

Pesch, U. and Vermaas, P.E. (2020), "The wickedness of Rittel and Webber's dilemmas", Administration and Society, Vol. 52 No. 6, pp. 960-979.

Petticrew, M. and Roberts, H. (2008), Systematic Reviews in the Social Sciences: A Practical Guide, Blackwell Publishing, Malden, MA.

Quarantelli, E.L. (Ed.) (1998), What is a Disaster? Perspectives on the Question, Routledge, New York, NY.

Ragini, J.R., Anand, P.R. and Bhaskar, V. (2018), "Big data analytics for disaster response and recovery through sentiment analysis", International Journal of Information Management, Vol. 42, pp. 13-24.

Raman, M., Kuppusamy, M.V., Dorasamy, M. and Nair, S. (2014), "Knowledge management systems and disaster management in Malaysia: an action research approach", Journal of Information \& Knowledge Management, Vol. 13 No. 1.

Rezaei, M., Akbarpour Shirazi, M. and Karimi, B. (2017), "IoT-based framework for performance measurement: a real-time supply chain decision alignment", Industrial Management and Data Systems, Vol. 117 No. 4, pp. 688-712.

Rittel, H.W.J. and Webber, M.M. (1973), "Dilemmas in a general theory of planning”, Policy Sciences, Vol. 4 No. 2, pp. 155-169. 
Roberts, J. (1991), "The possibilities of accountability", Accounting, Organizations and Society, Vol. 16 No. 4, pp. 355-368.

Rodríguez-Bolívar, M.P., Pérez, C.C. and Hernández, A.M.L. (2006), "Cultural contexts and governmental digital reporting", International Review of Administrative Sciences, Vol. 72 No. 2, pp. 269-290.

Rodríguez-Bolívar, M.P., Scholl, J. and Reddick, C.G. (Eds) (2021), "Blockchain and the public sector: theories", Reforms, and Case Studies, Springer.

Rodríguez-Espíndola, O., Chowdhury, S., Beltagui, A. and Albores, P. (2020), "The potential of emergent disruptive technologies for humanitarian supply chains: the integration of blockchain, artificial intelligence and 3D printing", International Journal of Production Research, Vol. 58 No. 15, pp. 4610-4630.

Rosenthal, U. and Kouzmin, A. (1997), "Crises and crisis management: toward comprehensive government decision making”, Journal of Public Administration Research and Theory, Vol. 7 No. 2, pp. 277-305.

Rotolo, D., Hicks, D. and Martin, B.R. (2015), "What is an emerging technology?”, Research Policy, Vol. 44 No. 10, pp. 1827-1843.

Sahebjamnia, N., Torabi, S.A. and Mansouri, S.A. (2017), "A hybrid decision support system for managing humanitarian relief chains", Decision Support Systems, Vol. 95, pp. 12-26.

Sardi, A., Sorano, E., Cantino, V. and Garengo, P. (2020), "Big data and performance measurement research: trends, evolution and future opportunities", Measuring Business Excellence.

Sargiacomo, M. and Walker, S.P. (2020), "Disaster governance and hybrid organizations: accounting, performance challenges and evacuee housing", Accounting, Auditing and Accountability Journal, doi: 10.1108/AAAJ-12-2019-4323.

Sargiacomo, M., Ianni, L. and Everett, J. (2014), “Accounting for suffering: calculative practices in the field of disaster relief", Critical Perspectives on Accounting, Vol. 25 No. 7, pp. 652-669.

Schumann, R.L. III (2018), "Ground truthing spatial disaster recovery metrics with participatory mapping in post-Katrina Mississippi”, Applied Geography, Vol. 99, pp. 63-76.

Sciulli, N. (2018), "Weathering the storm: accountability implications for flood relief and recovery from a local government perspective", Financial Accountability and Management, Vol. 34 No. 1, pp. 30-44.

Secundo, G., Ndou, V., Del Vecchio, P. and De Pascale, G. (2020), "Sustainable development, intellectual capital and technology policies: a structured literature review and future research agenda", Technological Forecasting and Social Change, Vol. 153, p. 119917.

Shah, S.A., Seker, D.Z., Rathore, M.M., Hameed, S., Yahia, S.B. and Draheim, D. (2019), "Towards disaster resilient smart cities: can internet of things and big data analytics be the game changers?”, IEEE Access, Vol. 7, pp. 91885-91903.

Shahat, E., Hyun, C.T. and Yeom, C. (2020), "Conceptualizing smart disaster governance: an integrative conceptual framework", Sustainability, Vol. 12 No. 22, p. 9536.

Sharma, S.K., Misra, S.K. and Singh, J.B. (2020), "The role of GIS-enabled mobile applications in disaster management: a case analysis of cyclone Gaja in India", International Journal of Information Management, Vol. 51, p. 102030.

Singh, J.P., Dwivedi, Y.K., Rana, N.P., Kumar, A. and Kapoor, K.K. (2019), "Event classification and location prediction from tweets during disasters", Annals of Operations Research, Vol. 283 Nos 1/2, pp. 737-757.

Sinha, A., Kumar, P., Rana, N.P., Islam, R. and Dwivedi, Y.K. (2019), "Impact of internet of things (IoT) in disaster management: a task-technology fit perspective", Annals of Operations Research, Vol. 283 Nos 1/2, pp. 759-794.

Snyder, H. (2019), "Literature review as a research methodology: an overview and guidelines”, Journal of Business Research, Vol. 104, pp. 333-339. 
MEDAR 30,4

Spanò, R. and Ginesti, G. (2021), "Fostering performance management in healthcare: insights into the role of big data", Meditari Accountancy Research.

Steen, T. and Brandsen, T. (2020), "Coproduction during and after the COVID-19 pandemic: will it last?”, Public Administration Review, Vol. 80 No. 5, pp. 851-855.

Stephenson, R. and Anderson, P.S. (1997), "Disasters and the information technology revolution", Disasters, Vol. 21 No. 4, pp. 305-334.

Sterman, J. (2014), "Interactive web-based simulations for strategy and sustainability: the MIT sloan learning edge management flight simulators, part I”, System Dynamics Review, Vol. 30 Nos 1/2, pp. 89-121.

Thekdi, S.A. and Chatterjee, S. (2019), "Toward adaptive decision support for assessing infrastructure system resilience using hidden performance measures", Journal of Risk Research, Vol. 22 No. 8, pp. 1020-1043.

Thorpe, R., Holt, R., Macpherson, A. and Pittaway, L. (2005), "Using knowledge within small and medium-sized firms: a systematic review of the evidence", International Journal of Management Reviews, Vol. 7 No. 4, pp. 257-281.

Tingey-Holyoak, J.L., Pisaniello, J.D. and Buss, P. (2021), "Embedding smart technologies in accounting to meet global irrigation challenges", Meditari Accountancy Research.

Toth, C. and Jozkow, G. (2016), "Remote sensing platforms and sensors: a survey", ISPRS Journal of Photogrammetry and Remote Sensing, Vol. 115, pp. 22-36.

Tranfield, D., Denyer, D. and Smart, P. (2003), "Towards a methodology for developing evidenceinformed management knowledge by means of systematic review", British Journal of Management, Vol. 14 No. 3, pp. 207-222.

Van Eck, N.J. and Waltman, L. (2014), "Visualizing bibliometric networks", in Ding Y, Rousseau R. and Wolfram D. (Eds), Measuring Scholarly Impact: Methods and Practice, Springer, Cham, pp. 285-320.

Van Eck, N.J. and Waltman, L. (2017), "Citation-based clustering of publications using CitNetExplorer and VOSviewer", Scientometrics, Vol. 111 No. 2, pp. 1053-1070.

Van Wart, M. and Kapucu, N. (2011), "Crisis management competencies: the case of emergency managers in the USA", Public Management Review, Vol. 13 No. 4, pp. 489-511.

Verbano, C. and Venturini, K. (2013), "Managing risks in SMEs: a literature review and research agenda", Journal of Technology Management and Innovation, Vol. 8 No. 3, pp. 186-197.

Von Lubitz, D.K., Beakley, J.E. and Patricelli, F. (2008), “All hazards approach to disaster management: the role of information and knowledge management, Boyd's OODA loop, and networkcentricity", Disasters, Vol. 32 No. 4, pp. 561-585.

Walker, S.P. (2014), "Drought, resettlement and accounting", Critical Perspectives on Accounting, Vol. 25 No. 7, pp. 604-619.

Wallace, W.A. and De Balogh, F. (1985), "Decision support systems for disaster management", Public Administration Review, Vol. 45, pp. 134-146.

Wang, H., Feng, J., Zhang, H. and Li, X. (2020a), "The effect of digital transformation strategy on performance: the moderating role of cognitive conflict", International Journal of Conflict Management, Vol. 31 No. 3, pp. 441-462.

Wang, L., Bivona, E., Yan, H. and Qi, J. (2020b), "Applying dynamic performance management to public emergency management: an analysis of the Wenchuan earthquake", in Bianchi, C. E., Luis, F., Luna-Reyes, L.F. and Rich, E. (Eds), Enabling Collaborative Governance through Systems Modeling Methods, Springer International Publishing, Berlin, pp. 263-276.

Waugh, W.L. (1995), "Geographic information systems: the case of disaster management", Social Science Computer Review, Vol. 13 No. 4, pp. 422-431.

Waugh, W.L. and Streib, G. (2006), "Collaboration and leadership for effective emergency management”, Public Administration Review, Vol. 66 No. s1, pp. 131-140. 
Wehn, U. and Evers, J. (2015), “The social innovation potential of ICT-enabled citizen observatories to increase eParticipation in local flood risk management", Technology in Society, Vol. 42, pp. 187-198.

Wisner, B., Blaikie, P., Cannon, T. and Davis, I. (2004), At Risk: Natural Hazards People's Vulnerability and Disaster, Routledge, London.

Xiao, Y. and Watson, M. (2019), "Guidance on conducting a systematic literature review”, Journal of Planning Education and Research, Vol. 39 No. 1, pp. 93-112.

Xiao, Y., Huang, Q. and Wu, K. (2015), "Understanding social media data for disaster management", Natural Hazards, Vol. 79 No. 3, pp. 1663-1679.

Yang, L., Yang, S.H. and Plotnick, L. (2013), "How the internet of things technology enhances emergency response operations", Technological Forecasting and Social Change, Vol. 80 No. 9, pp. 1854-1867.

Yu, M., Huang, Q., Qin, H., Scheele, C. and Yang, C. (2019), "Deep learning for real-time social media text classification for situation awareness - using Hurricanes Sandy, Harvey, and Irma as case studies", International Journal of Digital Earth, Vol. 12 No. 11, pp. 1230-1247.

Zagorecki, A.T., Johnson, D.E. and Ristvej, J. (2013), "Data mining and machine learning in the context of disaster and crisis management", International Journal of Emergency Management, Vol. 9 No. 4, pp. 351-365.

Zahra, K., Imran, M. and Ostermann, F.O. (2020), "Automatic identification of eyewitness messages on twitter during disasters", Information Processing and Management, Vol. 57 No. 1, p. 102107.

Zheng, T., Ardolino, M., Bacchetti, A. and Perona, M. (2020), "The applications of industry 4.0 technologies in manufacturing context: a systematic literature review", International Journal of Production Research, Vol. 59 No. 6.

Zwęgliński, T. (2020), "The use of drones in disaster aerial needs reconnaissance and damage assessment-three-dimensional modeling and orthophoto map study", Sustainability, Vol. 12 No. 15 , p. 6080.

\section{Further reading}

Choi, T.M., Wallace, S.W. and Wang, Y. (2018), "Big data analytics in operations management", Production and Operations Management, Vol. 27 No. 10, pp. 1868-1883.

Davis, F.D. (1989), "Perceived usefulness, perceived ease of use, and user acceptance of information technology", MIS Quarterly, Vol. 13 No. 3, pp. 319-340.

Kanbara, S., Ozawa, W., Ishimine, Y., Ngatu, N.R., Nakayama, Y. and Nojima, S. (2016), "Operational definition of disaster risk-reduction literacy", Health Emergency and Disaster Nursing, Vol. 3 No. 1, pp. 1-8.

Suárez, E., Calvo-Mora, A., Roldán, J.L. and Periáñez-Cristóbal, R. (2017), "Quantitative research on the EFQM excellence model: a systematic literature review (1991-2015)", European Research on Management and Business Economics, Vol. 23 No. 3, pp. 147-156.

Venkatesh, V. and Bala, H. (2008), "Technology acceptance model 3 and a research agenda on interventions", Decision Sciences, Vol. 39 No. 2, pp. 273-315.

\section{Corresponding author}

Carlo Vermiglio can be contacted at: cvermiglio@unime.it

For instructions on how to order reprints of this article, please visit our website:

www.emeraldgrouppublishing.com/licensing/reprints.htm

Or contact us for further details: permissions@emeraldinsight.com 